\title{
JM
}

Volume 6 No. 1 (April 2018)

(C) The Author(s)

\section{GAMBARAN PENGETAHUAN MASYARAKAT DALAM PEMANFAATAN POSYANDU DI DESA MARGO MULYO KABUPATEN BENGKULU TENGAH, AGUSTUS 2017}

\author{
DESCRIPTION OF PUBLIC KNOWLEDGE IN THE UTILIZATION OF THE \\ INTEGRATED HEALTH CENTER (POSYANDU) IN MARGO MULYO VILLAGE, \\ CENTRAL BENGKULU REGENCY, AUGUST 2017
}

\author{
YATRI HILINTI \\ DOSEN PRODI DIPLOMA III KEBIDANAN FIKES UNIVED BENGKULU \\ Email : yatrihilinti@rocketmail.com
}

\begin{abstract}
ABSTRAK
Pelayanan posyandu merupakan hal yang sangat penting bagi kesehatan ibu dan balita namun dalam kenyataannya masyarakat masih banyak yang tidak memanfaatkan program posyandu, hal ini terlihat dari jumlah belum tercapainya indikator imunisasi dasar lengkap pada balita. Dimana capaian indikator ini di Indonesia pada tahun 2015 sebesar 86,54\%. Angka ini belum mencapai target Renstra sebesar 91\%. Banyak faktor yang dapat mempengaruhi perilaku masyarakat dalam memanfaatkan posyandu diantaranya adalah pengetahuan masyarakat mengenai pemanfaatan posyandu. Penelitian ini bertujuan untuk mengetahui gambaran pengetahuan masyarakat dalam pemanfaatan posyandu di Desa Margo Mulyo Kabupaten Bengkulu Tengah Agustus 2017. Metode penelitian yang digunakan dalam penelitian ini adalah penelitian secara deskriptif, dengan jumlah sampel 64 responden diambil dengan teknik accidental sampling. Jenis data yang digunakan dalam penelitian ini menggunakan data primer dianalisis menggunakan analisis univariat. Hasil penelitian ini dapat disimpulkan bahwa lebih dari sebagian responden $37(57,8 \%)$, mempunyai pengetahuan kurang tentang pemanfaatan posyandu. Kepada pihak desa Margo Mulyo Kabupaten Bengkulu Tengah diharapkan agar dapat bekerjasama dengan pihak puskesmas maupun intansi kesehatan untuk dilakukan pemberian informasi kepada masyarakat khususnya ibu hamil maupun ibu yang mempunyai balita.
\end{abstract}

Kata kunci: Posyandu, Pengetahuan

\begin{abstract}
Posyandu services are very important for the health of mothers and toddlers but in reality, many people still do not take advantage of posyandu program, it can be seen from the number of attainment of complete basic immunization indicator in toddlers. Where the achievement of this indicator in Indonesia in 2015 amounted to 86.54\%. This figure has not reached the Renstra target of $91 \%$. Many factors that can influence the behavior of the community in using posyandu are public knowledge about the utilization of posyandu. This research aimed to determine the description of public knowledge in the utilization of posyandu in Margo Mulyo Village, Central Bengkulu District, August 2017. The research method used is a descriptive research, with the number of samples of 64 respondents taken by accidental sampling
\end{abstract}


technique. The type of data used in this research was using primary data which was analyzed using univariate analysis. The results of this research can be concluded that more than some respondents $37(57.8 \%)$, had less knowledge about posyandu utilization. To the village of Margo Mulyo, Central Bengkulu Regency is expected to be able to cooperate with the health centers and health institutions to provide information to the community, especially pregnant women and mothers who have a toddler.

\section{Keywords: Integrated Health Center, Knowledge}

\section{PENDAHULUAN}

Posyandu merupakan garda depan kesehatan balita dimana pelayanan yang diberikan posyandu sangat dibutuhkan untuk memberikan kemudahan dan keuntungan bagi kesehatan masyarakat, khususnya bayi dan balita. Tujuan Posyandu adalah menunjang penurunan Angka Kematian Ibu (AKI) dan Angka Kematian Bayi (AKB) di Indonesia melalui upaya pemberdayaan masyarakat. Sasaran pelayanan kesehatan di Posyandu adalah seluruh masyarakat terutama bayi, anak balita, ibu hamil, ibu melahirkan, ibu nifas dan ibu menyusui serta Pasangan Usia Subur (PUS) (Swengli, 2010).

Pengetahuan tentang posyandu merupakan hal yang sangat penting bagi ibu karena akan memberikan dampak positif terhadap ibu dalam memanfaatkan posyandu, hal ini dapat terjadi karena dengan adanya pengetahuan yang baik ibu akan dapat berfikir logis tentang pengaruh dari kegiatan posyandu untuk kehidupan ibu dan balitanya. Pengetahuan muncul ketika seseorang menggunakan indra atau akal budinya untuk mengenali kejadian yang belum pernah dilihat sebelumnya namun bisa didapatkan melalui pengalaman pribadi yang terjadi berulang kali (Fitriyani, 2013).

Banyak faktor yang dapat mempengaruhi perilaku masyarakat dalam memanfaatkan posyandu perilaku kesehatan dipengaruhi oleh beberapa faktor yaitu faktor prediposisi seperti pengetahuan, sikap, pendidikan, pekerjaan, umur, motivasi, jumlah anak balita, faktor pemungkin yaitu seperti kepemilikan KMS (Kartu Menuju Sehat), jarak posyandu, serta faktor penguat yaitu dukungan keluarga, dorongan tokoh masyarakat serta peran petugas kesehatan
(Notoatmodjo, 2010.

Rendahnya kunjungan ke posyandu pada ibu balita dapat menyebabkan banyaknya kasus tumbuh kembang anak tidak terpantau dengan baik sehingga kasus gizi kurang atau gizi buruk tidak terdeteksi secara dini, selain itu beberapa dampak lain yang dialami balita, bila ibu balita tidak aktif dalam kegiatan posyandu antara lain adalah : tidak mendapatkan penyuluhan kesehatan tentang pertumbuhan balita yang normal, tidak mendapatkan vitamin A untuk kesehatan mata balita dan ibu balita tidak mendapatkan pemberian dan penyuluhan tentang makanan tambahan (PMT) (Hairunida, 2012).

Pengetahuan ibu tentang posyandu merupakan hal yang sangat penting bagi ibu karena dengan kurangnya pengetahuan ibu tentang posyandu dapat menyebabkan rendahnya perilaku ibu dalam memanfaatkan posyandu sehingga ibu yang mempunyai balita tidak melakukan kunjungan sehingga bayi dan balita yang dimiliki ibu tidak dapat terpantau pertumbuhan dan perkembangan secara berkesinambungan.

Pelayanan posyandu merupakan hal yang sangat penting bagi kesehatan ibu dan balita namun dalam kenyataannya masyarakat masih banyak yang tidak memanfaatkan program posyandu hal ini terlihat dari jumlah belum tercapainya indikator imunisasi dasar lengkap pada balita. Dimana capaian indikator ini di Indonesia pada tahun 2015 sebesar 86,54\%. Angka ini belum mencapai target Renstra sebesar 91\%. Hanya sepuluh provinsi $(29 \%)$ yang mencapai target Renstra tahun 2015, termasuk provinsi Bengkulu dengan cakupan imunisasi dasar 89,25\% (Kemenkes RI, 2016).

Selain itu cakupan penimbangan balita di posyandu dari tahun 2010 sampai tahun 
2014 di Indonesia cenderung meningkat. Namun pada tahun 2015 terjadi penurunan menjadi 73,0\%, Cakupan tertinggi penimbangan balita terjadi di Provinsi Nusa Tenggara Barat sebesar 86,3\%, Cakupan penimbangan terendah terjadi di Provinsi Papua dan Papua Barat,sedangkan di provinsi Bengkulu 76,8\% (Kemenkes RI, 2016).

Berdasarkan data Dinas Provinsi Bengkulu juga diketahui bahwa jumlah ibu yang mempunyai balita yang melakukan penimbangan balita ke posyandu sebesar $77 \%$, kabupaten yang paling tinggi adalah kabupaten Bengkulu Utara sebesar 81\%, terbanyak kedua kabupaten Kaur sebesar $80 \%$, dan yang paling sedikit terdapat di kabupaten lebong sebesar $70 \%$, sedangkan di kabupaten Bengkulu Tengah cakupan ibu yang menimbang balita di posyandu sebesar 74\% (Dinkes Provinsi Bengkulu, 2016).

Jumlah Posyandu di Provinsi Bengkulu Tahun 2015 tercatat 1.886 posyandu. Untuk tingkat kemandirian posyandu diperoleh gambaran, bahwa untuk Posyandu Pratama sebanyak 378 (20\%), Posyandu Madya sebanyak 1055 (55\%), Posyandu Purnama sebanyak 410 (22\%) dan Posyandu Mandiri sebanyak 63 posyandu (3\%). Dan Jumlah posyandu aktif (purnama+mandiri) sebanyak 613 (32\%). Data provinsi Bengkulu kabupaten benteng merupakan kabupaten dengan penimbangan terendah ke 3 setelah kaur dan lebong yaitu 21\% (Dinkes Provinsi Bengkulu, 2016).

Data Depkes 2005-2006 jumlah kasus gizi buruk hingga saat ini masih memprihatikan. Tercatat jumlah anak balita yang terkena gizi buruk melonjak dari 1,8 juta (2005) menjadi 2,3 juta anak (2006). Dalam kurun waktu itu, lebih lima juta balita terkena gizi kurang, bahkan 10\% berakhir dengan kematian (Bapeda Jabar, 2006). Prevalensi (temuan kasus berbanding jumlah balita) pun cenderung meningkat dari tahun ke tahun, dan secara nasional, sebanyak 110 kabupaten kota di Indonesia mempunyai prevalensi gizi kurang (termasuk gizi buruk) di atas 30\%, yang menurut World Health Organization (WHO) dikelompokkan sangat tinggi
(Nurhayati, 2007).

Berdasarkan data Puskesmas Bentiring pada tahun 2015 seluruh ibu hamil di wilayah kerja Puskesmas bentiring berjumlah 114 orang dan di desa Margo Mulyo berjumlah 22 orang ibu hamil.Ibu hamil KEK diwilayah kerja puskesmas bentiring berjumlah 11 orang. Sedangkan, data puskesmas bentiring pada tahun 2016 seluruh ibu hamil di wilayah kerja Puskesmas bentiring berjumlah $125 \mathrm{ibu}$ hamil dan di desa Margo Mulyo berjumlah 22 orang ibu hamil. Ibu hamil KEK diwilayah kerja puskesmas bentiring berjumlah 12 orang.

Pada bulan Maret 2017 jumlah ibu hamil di wilayah kerja puskesmas yaitu 36 orang, sedangkan di desa Margo Mulyo 23 ibu hamil, Bulan Juni-Juli 2017 di wilayah kerja puskesmas bentiring berjumlah 40 orang ibu hamil. Jumlah balita usia 0-59 bulan di bulan Januari-Mei 2017 di desa Margo Mulyo yaitu 159 orang, sedangkan pada hasil penimbangan terdapat 29 balita berat badan mengalami Naik-Turun, 4 orang balita yang mengalami di garis kuning (Data Rekam Medik Puskesmas Bentiring).

\section{METODE PENELITIAN}

Desain penelitian yang digunakan dalam penelitian ini adalah penelitian survey yang bersifat deskriptif yaitu hanya menggambarkan atau mendeskripsikan variabel tertentu dalam suatu penelitian tanpa mencari hubungan variabel. Penelitian ini bertujuan mengetahui gambaran pengetahuan masyarakat dalam pemanfaatan posyandu di desa Margo Mulyo kabupaten Bengkulu. Penelitian ini dilakukan dengan mengumpulkan data melalui pertanyaan dari kuesioner. Populasi dalam penelitian ini adalah seluruh ibu hamil dan ibu yang memiliki Balitadi desa Margo Mulyo Kabupaten Bengkulu Tengah Januari-Mei 2017 yang berjumlah 180 orang. sampel dalam penelitian ini jumlah sampel yang dibutuhkan adalah 64 responden. 
HASIL PENELITIAN

1. Analisis Data.

Tabel 1. Distribusi Frekuensi Karakteristik Respoden di Desa Margo Mulyo Kabupaten Bengkulu Tengah Agustus 2017

Karakteristik Frekuensi (f) Persentase ( \% )

\begin{tabular}{ccc}
\hline Usia & & \\
\hline$<20$ Tahun & 2 & 3.1 \\
\hline $20-35$ Tahun & 52 & 81.2 \\
\hline$>35$ Tahun & 10 & 15.6 \\
\hline Pendidikan & & \\
\hline SD & 19 & 29,7 \\
\hline SMP & 35 & 54,7 \\
\hline SMA & 10 & 15,6 \\
\hline Pekerjaan & & \\
\hline Tidak bekerja & 63 & 98,4 \\
\hline Bekerja & 1 & 1,6 \\
\hline Paritas & & \\
\hline Nulipara & 4 & 6,2 \\
\hline Primipara & 16 & 25,0 \\
\hline Multipara & 44 & 68,8 \\
\hline Total & 64 & 1000 \\
\hline
\end{tabular}

Berdasarkan tabel 1 dapat diketahui bahwa dari 64 responden terdapat sebagian kecil dari responden $2(3,1 \%)$ mempunyai usia $<20$ tahun, hampir seluruh responden $52(81,2 \%)$ mempunyai usia 20-35 tahun, sebagian kecil dari responden 10(15,6\%) mempunyai usia $>35$ tahun. Hampir sebagian responden $19(29,7 \%)$ mempunyai pendidikan $\mathrm{SD}$, lebih dari sebagian responden $35(54,7 \%)$ mempunyai pendidikan SMP, sebagian kecil dari responden $10(15,6 \%)$ mmpunyai pendidikan SMA. Hampir seluruh respoden 63(98,4\%) tidak bekerja, sebagian kecil dari responden 1(1,6\%) bekerja. Sebagian kecil dari responden $4(6,2 \%)$ mempunyai paritas nulipara, sebagian kecil dari responden $16(25,0 \%)$ mempunyai paritas primipara, dan lebih dari sebagian responden 44(68,8\%) mempunyai paritas multipara.

Tabel 2. Distribusi Frekuensi Pengetahuan Masyarakat dalam Pemanfaatan Posyandu di Desa Margo Mulyo Kabupaten
Bengkulu Tengah Agustus 2017

\begin{tabular}{ccc}
\hline Pengetahuan & Frekuensi (f) & Persentase ( \% ) \\
\hline Kurang & 37 & 57,8 \\
\hline Cukup & 21 & 32,8 \\
\hline Baik & 6 & 9,4 \\
\hline Jumlah & 64 & 100,0 \\
\hline
\end{tabular}

Berdasarkan tabel 2 dapat diketahui bahwa dari 64 responden terdapat lebih dari sebagian besar responden 37(57,8\%), mempunyai pengetahuan kurang tentang pemanfaatan posyandu, hampir sebagian responden 21(32,8\%) mempunyai pengetahuan cukup tentang pemanfaatan posyandu, dan sebagian kecil dari responden $6(9,4 \%)$ mempunyai pengetahuan baik tentang pemanfaatan posyandu.

\section{PEMBAHASAN}

\section{Gambaran Karakteristik Masyarakat dalam Pemanfaatan Posyandu di Desa Margo Mulyo Kabupaten Bengkulu Tengah Agustus 2017.}

Hasil penelitian ini menunjukkan bahwa dari 64 responden terdapat sebagian kecil responden $2(3,1 \%)$ mempunyai usia $<20$ tahun.Hasil penelitian ini menggambarkan bahwa dilihat dari usia responden belum cukup matang untuk menyerap pengetahuan.

Menurut Mubarak (2012), dengan bertambahnya umur seseorang akan mengalami perubahan aspek fisik dan psikologis (mental). Secara garis besar pertumbuhan fisik secara garis besar ada empat kategori perubahan, yaitu perubahan ukuran, perubahan proporsi, hilangnya ciriciri lama dan timbulnya ciri-ciri baru. Ini terjadi akibat pematangan fungsi organ. Pada aspek psikologis dan mental, taraf berfikir seseorang semakin matang dan dewasa, dengan kata lain jika usia seseorang bertambah maka pola fikir, serta kemampuan berfikir seseorang akan lebih baik jika dibandingkan dengan seorang yang belum dewasa.

Hasil analisis pendidikan responden 
diketahui bahwa lebih dari sebagian responden $35 \quad(54,7 \%)$, mempunyai pendidikan SMP. Melihat karakteristik responden yang demikian dimana, pendidikan responden masih banyak responden yang mempunyai pendidikan SMP hal ini dapat menjadikan salah satu faktor yang dapat mempengaruhi pengetahuan seseorang dalam memahami pengetahuan yang baru.

Menurut Wawan dan Dewi (2010), pendidikan adalah suatu usaha untuk mengembangkan kepribadian dan kemampuan di dalam dan di luar sekolah dan berlangsung seumur hidup. Makin tinggi tingkat pendidikan seseorang, makin mudah menentukan dan menerima informasi. Semakin banyak informasi yang masuk, semakin banyak pula pengetahuan yang didapat tentang kesehatan. Sebaliknya, pendidikan yang kurang akan menghambat perkembangan sikap seseorang terhadap nilainilai yang baru diperkenalkan.

Karakteristik pekerjaan responden pada penelitian ini menunjukkan bahwa hampir seluruh respoden $63(98,4 \%)$, tidak bekerja. Hasil peneltian ini menggambarkan bahwa responden mempunyai kecenderungan tidak berkerja, dengan banyaknya ibu yang tidak bekerja ini dapat menyebabkan kurangnya aksesinformasi yang didapat. Hal ini sesuai dengan pendapat Mubarak (2012), dimana lingkungan pekerjaan dapat menjadikan seseorang memperoleh pengalaman dan pengetahuan, baik secara langsung maupun secara tidak langsung.

Namun dengan adanyanya ibu yang tidak bekerja dapat meningkatkan banyak waktu ibu dalam melakukan aktivitas dalam menjaga anak serta membawa anaknya keposyandu Notoatmodjo (2011) berpendapat bahwa individu yang berbeda pekerjaan mempunyai kecenderungan yang berbeda pula dalam menggunakan pelayanan kesehatan. Hasil penelitian ini berbeda dengan penelitian yang dilakukan oleh Yuliasari (2010) yang melaporkan bahwa ibu yang tidak bekerja atau ibu yang aktifitas sehari-harinya hanya sebagai ibu rumah tangga memiliki peluang atau kesempatan yang lebih besar dalam memanfaatkan pelayanan yang ada di posyandu dibandingkan dengan ibu yang bekerja.

Dilihat dari karakteristik paritas responden diketahui bahwa sebagian besar responden $44(68,8 \%)$, mempunyai paritas multipara. Hal ini menggambarkan bahwa rata-rata ibu sudah pernah mempunyai pengalaman yang baik dalam melakukan perawatan pada anaknya, tetapi dengan kesibukan dan waktu yang terbatas dalam mengurus rumah tangga dan anaknya sehiungga membuat ibu-ibu sulit membagikan waktu untuk datang keposyandu.

Menurut mubarak (2012), pengalaman adalah suatu kejadian yang pernah dialami seseorang dalam berinteraksi dengan lingkungannya. Ada kecenderungan pengalaman yang kurang baik seseorang akan berusaha untuk melupakan, namun jika pengalaman terhadap objek tersebut menyenangkan maka secara psikologis akan timbul kesan yang membekas dalam emosi sehingga menimbulkan sikap positif.

\section{Gambaran Pengetahuan Masyarakat dalam Pemanfaatan Posyandu di Desa Margo Mulyo Kabupaten Bengkulu Tengah Agustus2017}

Hasil penelitian ini menunjukkan bahwa dari 64 responden terdapat lebih dari sebagian responden $37 \quad(57,8 \%)$ mempunyai pengetahuan kurang tentang pemanfaatan posyandu. Hasil penelitian ini juga menunjukkan bahwa jawaban kuesioner yang paling banyak dijawab salah oleh responden antara lain, 67\% responden menjawab salah tentang pengelompokan posyandu menjadi empat strata atau tingkatan, 64\% responden menjawab salah tentang pengertian Posyandu, $63 \%$ menjawab salah tentang kegiatan pokok Posyandu, 53\% menjawab salah tentang imunisasi yang dilakukan saat posyandu. Masih rendahnya pengetahuan masyarakat mengenai pemanfaatan posyandu ini dapat terjadi karena kurangnya informasi yang diberikan oleh petugas kesehatan maupun 
kader posyandu mengenai pemanfaatan posyandu maupun pengaruh tingkat pendidikan masyarakat dimana diketahui bahwa pendidikan responden rata-rata SMP.

Hasil penelitian ini sedikit berbeda dengan penelitian Pramono (2014), dengan judul hubungan antara pengetahuan ibu tentang posyandu dan dukungan keluarga dengan perilaku kunjungan balita ke posyandu Suka Damai di Kecamatan Marangkayu Kabupaten Kutai Kartanegara menunjukkan responden dengan kunjungan baik terbanyak dijumpai pada tingkat pengetahuan baik $(49,5 \%)$, disusul tingkat pengetahuan cukup baik $(25,7 \%)$, kurang baik $(22,0 \%)$ dan yang paling sedikit tingkat pengetahuan tidak baik (2,8\%).

Masih rendahnya pengetahuan masyarakat mengenai pemanfaatan posyandu dapat mempengaruhi perilaku masyarakat dalam memanfaatkan posyandu yang hal ini dapat terjadi karena pengetahuan merupakan domain penting bagi seseorang dalam melakukan tindakan ataupun berperilaku yang baik dalam mencapai kesehatan yang maksimal untuk dirinya. Dengan kata lain jika masyarakat mengetahui lebih banyak tentang manfaat posyandu dapat mempengaruhi sikap maupun motivasimasyarakat dalam memanfaatkan posyandu sehingga yang ahirnya dapat berpengaruh terhadap perilaku ibu dalam memanfaatkan posyandu yang ada.

Menurut Yuliana (2014), pengetahuan mengenai posyandu merupakan hal yang sangat penting karena dengan kurangnya pengetahuan yang dimiliki ibu akan meningkatkan pemanfaatan posyandu yang kurang baik, sehingga dapat menyebabkan beberapa kerugian pada balita, bila ibu balita tidak aktif dalam kegiatan Posyandu antara lainibu tidak mendapatkan penyuluhan kesehatan tentang pertumbuhan balita yang normal, tidak mendapat vitamin A untuk kesehatan mata, ibu balita tidak mengetahui pertumbuhan berat badan balita tiap bulan, ibu balita tidak mendapatkan pemberian dan penyuluhan tentang makanan tambahan (PMT). Ibu yang aktif dalam kegiatan Posyandu maka ibu balita dapat memantau tumbuh kembang balitanya.

Menurut Mubarak (2012), pengetahuan adalah kesan dalam pikiran manusia sebagai hasil penggunaan panca indranya. Pengetahuan sangat berbeda dengan dengan kepercayaan (biliefs), takhayul (superstition), dan penerangan-penerangan yang keliru (misinformation). Pengetahuan adalah segala apa yang diketahui berdasarkan pengalaman yang didapat oleh setiap manusia.

Notoatmodjo (2011), menjelaskan terbentuknya perilaku baru, terutama pada orang dewasa dimulai dari domain kognitif, dalam arti subyek tahu terlebih dahulu terhadap stimulus yang berupa materi atau objek di luarnya. Kemudian menimbulkan pengetahuan baru pada subjek tersebut. Akhirnya rangsangan yakni objek yang telah diketahui dan disadari sepenuhnya akan menimbulkan respon yang lebih jauh lagi yaitu berupa tindakan (action) terhadap atau berhubungan dengan stimulus atau objek tersebut. Namun apabila respon dari stimulus tersebut tidak dibarengi dengan respon yang positif dari seseorang perilaku tersebut tidak akan berlangsung lama.

Wawan dan Dewi (2011) menyatakan bahwa faktor pengetahuan, pendidikan, informasi dan pengalaman mempunyai dampak dalam menentukan perilaku ibu terhadap anak mereka sehingga antara pengetahuan dan perilaku akan saling berhubungan baik secara langsung maupun tidak langsung.

Masih banyak responden yang mempunyai pengetahuan kurang dan cukup hal ini dapat dipengaruhi oleh beberapa faktor seperti teori yang dikemukakan oleh Mubarak (2012) yang menyatakan bahwa Ada tujuh faktor yang mempengaruhi pengetahuan seseorang, yaitu, pendidikan, pekerjaan, umur, minat, pengalaman, kebudayaan dan informasi.

ndani (2011), menyatakan bahwa pendidikan yang baik diharapkan dapat mempengaruhi prilaku untuk memelihara kesehatan dan meningkatkan kesehatan yang lebih kondusif. Tingkat pendidikan seseorang berpengaruh dalammemberikan respon 
terhadap sesuatu yang datang dariluar. Orang berpendidikan tinggi akan lebih rasional dankreatif serta terbuka dalam menerima adanya bermacam usaha pembaharuan, ia juga akan lebih dapatmenyesuaikan diri terhadap berbagai perubahan. pendidikan yang dicapai seseorang diharapkan menjadi faktor determinan produktifitas antara lain knowledge, skills,abilities, attitude dan behavior, yang cukup dalam menjalankan aktifitas pekerjaanya.

Berdasarkan hasil penelitian ini dan beberapa teori yang telah dipaparkan sebelumnya dapat disimpulkan bahwa pengetahuan masyarakat mengenai pemanfaatan posyandu merupakan hal yang sangat penting untuk meningkatkan motivasi masayarakat maupun keluarga dalam memanfaatkan posyandu yang ada. Namun dalam kenyaataannya masih hanya sedikit saja masayarakat yang mengetahui manfaat posyandu dan masih banyak masyarakat yang tidak mengetahui tentang manfaat posyandu. Masih kurangnya pengetahuan masyarakat terhadap pemanfaatan posyandu dapat disebabkan karena faktor kurangnya informasi maupun faktor pendidikan mayarakat maupun karakteristik individu lainnya.

Mengingat masih banyaknya masyarakat yang mempunyai pengetahuan kurang baik tentang pemanfaatan posyandu ini maka perlu berbagai upaya untuk meningkatkan pengetahuan masyarakat mengenai pentingnya pemanfaatan posyandu dengan memberikan informasi kepada masyarakat dengan penyuluhan rutin kepada masyarakat terutama pada ibu hamil maupun ibu yang mempunyai bayi ataupun balita sehingga dengan adanya penyuluhan tersebut masyarakat dapat lebih memahami tentang pentingnya pemanfaatan posyandu.

\section{KESIMPULAN}

Hasil penelitian tentang pengetahuan masyarakat dalam pemanfaatan posyandu di Desa Margo Mulyo Kabupaten Bengkulu Tengah Agustus 2017 dapat ditarik kesimpulan sebagai berikut :

1. Lebih dari sebagian responden (57,8\%) mempunyai pengetahuan kurang tentang pemanfaatan Posyandu di desa Margo Mulyo Kabupaten Bengkulu Tengah Agustus 2017.

2. Hampir seluruh responden (81,2\%) mempunyai usia 20-35 tahun di Desa Margo Mulyo Kabupaten Bengkulu Tengah Agustus 2017.

3. Lebih dari sebagian responden $(54,7 \%)$ mempunyai pendidikan SMP di Desa Margo Mulyo Kabupaten Bengkulu Tengah Agustus 2017.

4. Hampir seluruh respoden (98,4\%) tidak bekerja di Desa Margo Mulyo Kabupaten Bengkulu Tengah Agustus 2017.

5. Lebih dari sebagian responden $(68,8 \%)$ mempunyai paritas multipara di Desa Margo Kabupaten Bengkulu Tengah Agustus 2017.

\section{SARAN}

Berdasarkan hasil penelitian yang telah dilakukan maka peneliti memberi saran kepada:

1. Desa Margo Mulyo Kabupaten Bengkulu Tengah.

Kepada pihak desa Margo Mulyo Kabupaten Bengkulu Tengah diharapkan agar dapat bekerjasama dengan pihak puskesmas maupun intansi kesehatan untuk dilakukan pemberian informasi kepada masyarakat khususnya ibu hamil maupun ibu yang mempunyai balita dengan harapan jika adanya informasi yang tepat tentang pemanfaatan posyandu dapat meningkatkan pengetahuan masyarakat mengenai pemanfaatan posyandu sehingga masyarakat akan termotivasi dalam memanfaatkan posyandu.

\section{AKBID Dehasen Bengkulu.}

Kepada pihak akademik diharapkan dapat ikut serta dalam segala kegiatan 
yang dilaksanakan pemerintah dan mau peduli akan pentingnya pemanfaatan posyandu dengan menuntun mahasiswa untuk memberikan informasi kepada masyarakat terkait dengan pemanfaatan posyandu kepada masyarakat.

3. Peneliti selanjutnya

Kepada peneliti selanjutnya diharapkan bagi peneliti berikutnya agar berupaya lebih mengembangkan dan memperdalam bahasan penelitian ini dengan melihat adanya pengaruh pengetahuan dengan perilaku masyaradalam memanfaatkan posyandu dengan desain yang berbeda seperti desain cross sectional

\section{DAFTAR PUSTAKA}

Alhudawi. (2010). Hubungan Pengetahuan, Sikap dan Keaktifan Keluarga terhadap Program Posyandu dengan Status Gizi Balita di Kelurahan Ujung Padang. Karya Tulis Ilmiah. Fakultas Kedokteran Universitas Sumatera Utara Medan.

Arsita, E.P. (2011). Ilmu Kesehatan Masyarakat Untuk Kebidanan Holistik Nuha Medika: Yogyakarta

Dinkes Provinsi Bengkulu. (2016) Profil Data Kesehatan Provinsi Bengkulu tahun 2015. Dinas Kesehatan Provinsi Bengkulu

Endang P, dkk. (2015) Ilmu Kesehatan Masyarakat Dalam Kebidanan. Pustaka Baru Press: Yogyakarta.

Hairunida. (2012). Faktor Yang Berhubungan Dengan Perilaku Kunjungan Ke Posyandu Pada Ibu Balita Di Wilayah Kerja Puskesmas Pancoran Mas Kota Depok Tahun 2012. Skripsi. Fakultas kesehatan masyarakat Peminatan kebidanan komunitas Depok

Hidayat, A, A. (2008). Metode Penelitian Keperawatan Teknik Analisa Data. Salemba Medika: Jakarta

Kemenkes RI. (2011). Petunjuk Pelaksanaan Pelatihan Kader Posyandu.
Kementerian Kesehatan RI: Jakarta.

Kemenkes RI. (2012) Buku Saku Posyandu. Pusat Promosi Kesehatan Kementerian Kesehatan RI: Jakarta.

Kemenkes RI. (2016). Profil Kesehatan Indonesia 2015. Kementrian Kesehatan Republik Indonesia: Jakarta.

Khotimah. (2008). Faktor-Faktor Yang Berhubungan Dengan Peran Serta Ibu Membawa Anaknya Untuk Diimunisasi Di Desa Sugih Waras Kecamatan Rambang Kabupaten Muara Enim. Dosen Jurusan Gizi Poltekkes Dep. Kes. Palembang. ILMIAH Volume III No.1, 2010. ISSN: 1979-0759.

Mubarak. (2012). Promosi Kesehatan Untuk Kebidanan. Salemba Medika: Jakarta.

Notoatmodjo. (2010) Metodologi Penelitian Kesehatan. PT Rineka Cipta: Jakarta.

Notoatmodjo. (2010) Ilmu prilaku kesehatan. PT Rineka Cipta: Jakarta

Notoatmodjo. (2011) Ilmu KesehatanMasyarakat. PT Rineka Cipta: Jakarta

Olivia. (2011) Faktor-Faktor Yang Berhubungan Dengan Perilaku Kunjungan Ibu Yang Mempunyai Balita Ke Posyandu Di Wilayah Kerja Puskesmas Kota Solok. Fakultas Kesehatan Masyarakat Program Sarjana Kesehatan Masyarakat Peminatan Kebidanan Komunitas Depok

Suharti. (2012). Hubungan Faktor Pengetahuan, Sikap Dan Dukungan Keluarga Dengan Perilaku Kunjungan Ke Posyandu Pada Ibu Pekerja Di Banjarnegara Jawa Tengah. Skripsi. Peminatan Kebidanan Komunitas Fakultas Kesehatan Masyarakat Universitas Indonesia Depok

Wawan dan Dewi (2010). Teori dan pengukuran pengetahuan, sikap dan prilaku manusia. Yuha Medika: Yogyakarta. 